\title{
ТЕНДЕНЦІЇ РОЗВИТКУ МЕТОДІВ І СИСТЕМ УПРАВЛІННЯ ВІДХОДАМИ
}

Нині за кордоном утилізують відходи швидше, ніж вони накопичуються. Для цього використовують альтернативні методи та екологічні матеріали, які мінімізують їх утворення. В Україні використовують шкідливі матеріали, які забруднюють довкілля, а також відсутні екологічні методи утилізації відходів. В Україні однією з найважливіших і найактуальніших проблем забруднення довкілля є неконтрольоване накопичення відходів та захоронення на полігонах. Проаналізовано основні тенденції розвитку методів і систем управління відходами. Оцінено сучасний стан та проблеми управління відходами в Україні та Львівській області. Виявлено тенденцію постійного зростання обсягу відходів. Простежено динаміку утворення відходів за категоріями матеріалів та класами небезпеки. Виконано аналіз утворення та утилізації відходів у Львівській області за 2010-2017 рр. Виконано регресійний аналіз зміни обсягу спалених відходів у Львівській області для отримання енергії і зміни показників утворення відходів I класу небезпеки. Встановлено, що відходи I класу небезпеки з 2000 по 2017 рp. $3 м і-$ нюються в поліноміальній залежності 2-го степеня. Використання цих залежностей дасть змогу спрогнозувати зміни обсягів відходів у Львівській області. В Україні для сталого розвитку потрібно впроваджувати інтегровані системи управління відходами на регіональному та локальному рівнях. Тому для оптимальної моделі управління відходами потрібно запобігати утворенню та накопиченню відходів та повторно використовувати ті, що містяться на полігонах та сміттєзвалищах.

Ключові слова: відходи; системи управління відходами; Львівщина; перероблення відходів; опрацювання статистичних даних; показники утворення та утилізації відходів.

Вступ. Нині стратегія сталого розвитку є пріоритетним напрямом для досягнення гармонії між ростом економічних показників, стабільністю в соціальній сфері та охороною довкілля. Забезпечення сталого розвитку будь-якої держави супроводжується створенням безпечного стану довкілля для нинішнього і майбутніх поколінь. Тому екологічна безпека $\epsilon$ елементом системи сталого розвитку. В Україні однією з найважливіших і найактуальніших проблем забруднення довкілля $\epsilon$ неконтрольоване накопичення відходів, їх захоронення на полігонах, більшість з яких є перевантаженими.

Проблема утворення, накопичення та ефективного управління відходами $є$ нагальною не тільки для Львова чи України, а й для більшості країн світу. Нині Швейцарія та Німеччина утилізують відходи швидше, ніж вони накопичуються, вони використовують альтернативні методи та екологічні матеріали, які мінімізують їх утворення. Навпаки, в Україні використовують шкідливі матеріали, які забруднюють довкілля, а також відсутні екологічні методи утилізації відходів.

Управління відходами - збирання, перевезення, оброблення (включаючи відновлення та видалення), нагляд за такими операціями і подальший контроль, догляд за об'єктами видалення відходів після їх закриття.

На рис. 1 показано управління відходами у різних країнах Європи. Згідно 3 наведеними даними, можна констатувати, що від захоронення відходів цілком відмовилася тільки Швейцарія, до того ж вона використовує тільки чисті технології - спалювання з відновленням енергії, порівнянні з Німеччиною, яка використовує метод спалювання відходів без отримання енергії. Однак, 3-поміж усіх інших країн, саме Німеччина найближче наслідує позиції Швейцарії щодо практичної відмови від захоронення на полігонах.

Отже, впродовж десятки років країни Свропи отримали досвід з утилізації відходів, удосконалюючи методи управління відходами відповідно до своїх особливостей (Vadivala \& Vagnani, 2015; Worlds Cities, 2009; Scheinberg, 2008; Petruk, 2007; Shanina et al., 2012).

Аналіз останніх досліджень та публікацій. Дослідження сучасного стану, закономірностей утворення, шляхів оброблення та утилізації побутових відходів в Україні викладено у працях (Petruk et al., 2016; Samoilik \& Molchanova, 2017; Pavlikha, Dubynchuk \& Androshchuk, 2016; Babaiev et al., 2017; Mitryasova et al., 2016; Filipovych, Kudriashov \& Mychak, 2015; Andronov et al., 2017; Bodnar \& Poltorachenko, 2011). Проблеми утворення відходів у Львівській обл. висвітлено у працях (Krupka \& Lototska-Dudyk, 2015; Bukhta, 2018; Kalyn, Matsuska \& Romanyshyn, 2017). Унаслідок цих дослі-

\section{Інформація про авторів:}

Погребенник Володимир Дмитрович, д-р техн. наук, професор, кафедра екологічної безпеки та природоохоронної діяльності. Email: vpohreb@gmail.com; https://orcid.org/0000-0002-1491-2356

Коваль Ірина Ігорівна, мол. наук. співробітник, кафедра екології та збалансованого природокористування. Email: iralito@i.ua Джумеля Ельвіра Анатоліївна, аспірант, кафедра екологічної безпеки та природоохоронної діяльності.

Email: elviradzhumelia@gmail.com; https://orcid.org/0000-0003-3146-8725

Цитування за Дсту: Погребенник В. Д., Коваль І. І., Джумеля Е. А. Тенденції розвитку методів і систем управління відходами. Науковий вісник НЛтУ України. 2019, т. 29, № 1. С. 78-82.

Citation APA: Pohrebennyk, V. D., Koval, I. I., \& Dzhumelia, E. A. (2019). Trends of Development of Methods and Management Systems of Waste. Scientific Bulletin of UNFU, 29(1), 78-82. https://doi.org/10.15421/40290117 
джень, які виконано впродовж 2010-2016 рр., встановлено незмінну тенденцію в неефективному управлінні побутовими відходами. Однак такі дослідження не $є$ достатніми для вирішення проблем утворення, накопичення та утилізації побутових відходів Львівської області.

Мета роботи - проаналізувати основні тенденції розвитку методів і систем управління побутовими відходами.

Матеріали і методи дослідження. Серед теоретичних методів використано методи аналізу і синтезу для узагальнення літературних джерел та виявлення основних напрямів досліджень. Формалізацію результатів моделювання виконано 3 використанням програмно- функціонального забезпечення MS Excel. Методи математичної статистики застосовано для опрацювання отриманих експериментальних даних, оцінювання їх достовірності та відтворюваності.

Результати дослідження та їх обговорення. В Україні нараховується 6,5 тис. законних і близько 35 тис. незаконних сміттєзвалищ. Найбільші сміттєзвалища України показано на рис. 2. Ситуація щороку погіршується. За підрахунками екологів, Україна накопичила 54 млн м ${ }^{3}$ відходів; щороку сміттєві полігони поповнюються приблизно на 15-17 млн т. На перероблення йде лише десята частина зібраного сміття.

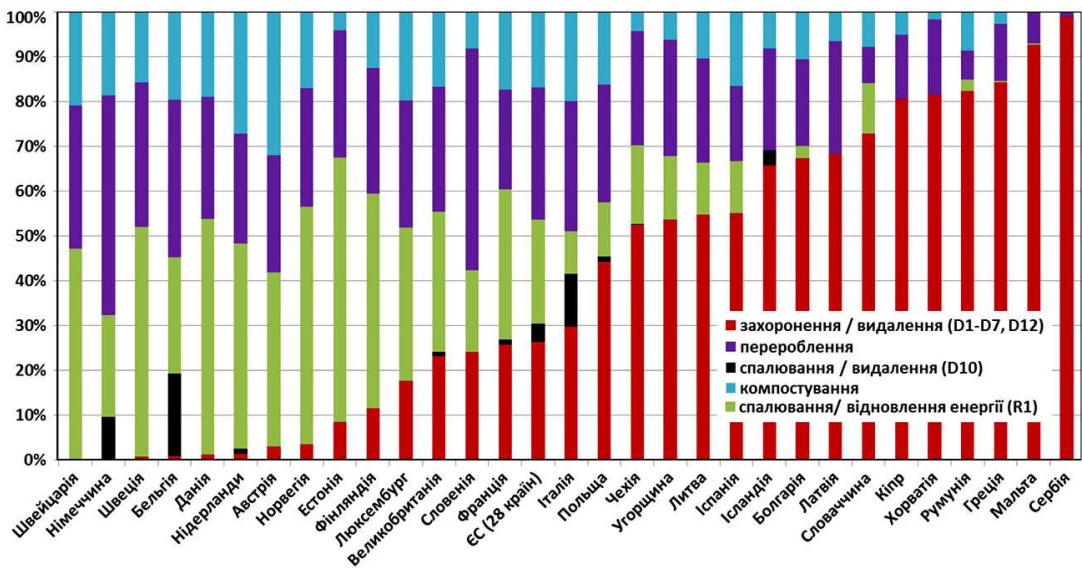

Рис. 1. Управління відходами у країнах Європи

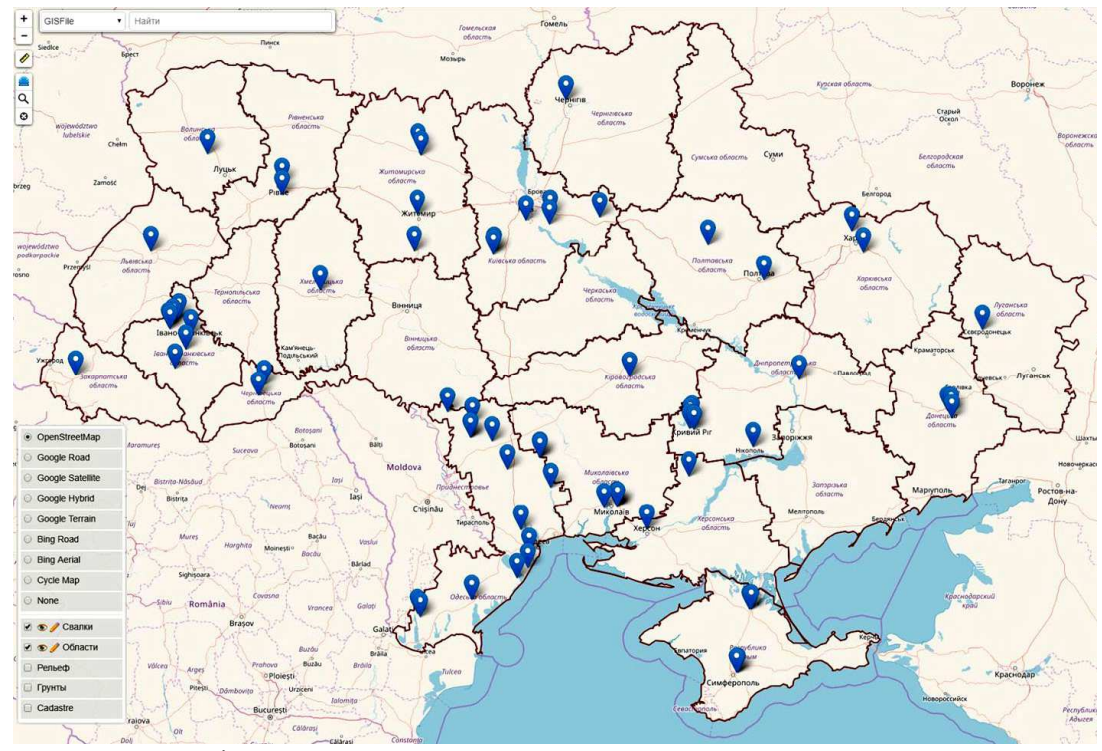

Рис. 2. Найбільші полігони ПВ в Україні

За щорічними даними Мінрегіонбуду обсяг утворення відходів в Україні впродовж 2011-2017 рр. становив: у 2011 р. - близько 52 млн м ${ }^{3}$, у 2012 та 2013 pp. близько 59 млн м ${ }^{3}$, а у 2014 р. (без урахування даних АР Крим, Луганської обл. та м. Севастополь) - близько 45 млн м ${ }^{3}$, у 2015 р. - близько 48 млн м ${ }^{3}$, у 2016 р. 49 млн м ${ }^{3}$, у 2017 р. - близько 52 млн м ${ }^{3}$.

Аналізуючи наведені дані, потрібно відзначити значне коливання в утворенні ПВ у проміжках 2013 та 2014 рр., де відбулося стрімке зменшення їх накопичення, що пов'язано з проявом у цей період кризових явищ в економіці та їх наслідків у державі. Однак ці чи інші статистичні дані обсягів утворення ПВ в Україні не відображають реальну ситуацію, а тому не є точними. Однією 3 причин встановлення Мінрегіоном таких приблизних даних є малий відсоток (близько $20 \%$ ) на- селення України, які не охоплено послугою вивезення ПВ. Тому таке явище, як створення несанкціонованих звалищ, самовільне засмічення територій тощо, набуло великих масштабів та відповідно до цього неофіційні показники можуть бути значно більшими. Другою причиною цих неточних даних є відсутність налагодженої практики зважування ПВ. Зазвичай облік ведуть в одиницях об'єму - кубічних метрах $\left(\mathrm{m}^{3}\right)$. Перерахунок в одиниці маси (т) здійснюють зважаючи на густину ТПВ, яка становить близько $0,2-0,3$ т/м³. За даними різних авторів, нині в Україні рівень перероблення ПВ становить 10-12\%. Для європейських країн цей показник становить 85-90 \%, для інших країн світу - $65 \%$.

Нині в Україні домінуючими методами управління ПВ залишаються традиційні технології їх утилізації - спалювання та розміщення й захоронення відходів на несанкці- 
онованих звалищах і спеціальних полігонах, які перевантажені та не відповідають нормам екологічної безпеки.

Нині Львівська обл., зокрема місто Львів, активно продовжують використовувати застарілий спосіб управління побутовими відходами. Не зупиняє той факт, що із 1 січня 2018 р. в Україні запрацювали зміни до Закону "Про відходи", які передбачають сортування сміття та заборону на поховання неперероблених побутових відходів. Причиною такої незмінної ситуації є чинний Закон України "Про відходи", який не має переліку та послідовності операцій із сміттям.

Структуру відходів Львівської обл., України та Свропи показано у таблиці (Krupka \& Lototska-Dudyk, 2015). Відповідно до цих даних харчові відходи переконливо переважають серед інших в Свропі, Україні та на Львівщині. Проаналізувавши структуру інших видів відходів Львівської обл., з'ясовано, що переважають відходи вторинних матеріалів, деревини та інших матеріалів. Така саме тенденція є характерною для України. Натомість в Європі переважають відходи з паперу, великогабаритних матеріалів і вторинних матеріалів.

Таблиця. Структура відходів, \%

\begin{tabular}{|l|c|c|c|}
\hline \multicolumn{1}{|c|}{ Вид відходів } & Львівщина & Україна & Свропа \\
\hline Харчові відходи & 35 & 45 & 35 \\
\hline Вторинні полімери & 30 & 13 & 12 \\
\hline Папір, картон & 8 & 10 & 33 \\
\hline Великогабаритні матеріали & - & - & 10 \\
\hline Скло & 12 & 8 & 3 \\
\hline Текстильні матеріали & 2 & 6 & - \\
\hline Метали & 4 & 3 & 5 \\
\hline Деревина & 10 & 1 & 2 \\
\hline Будівельне сміття & 6 & 5 & - \\
\hline
\end{tabular}

Упродовж останніх років обсяг утворених побутових відходів у Львівській обл. зростає (рис. 3) через зміни способу життя (досягнення надмірної комфортності) та недооцінювання населенням природних реакцій на відсутність екологічної рівноваги.

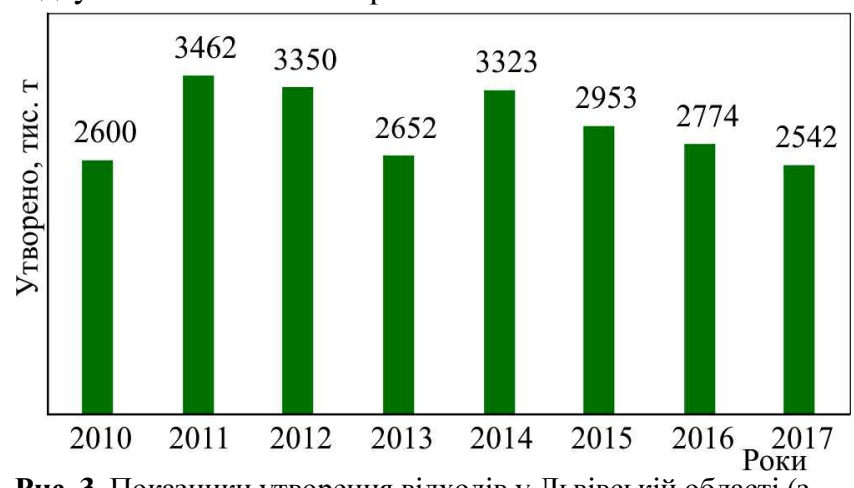

Рис. 3. Показники утворення відходів у Львівській області (3 урахуванням обсягів відходів, зібраних підприємствами від домогосподарств)

У 2017 р. у Львівській обл. було спалено 337 тис. т відходів, утилізовано - 646 тис. т (рис. 4). Зміна обсягу спалених відходів у Львівській обл. для отримання енергії відбувається за поліноміальною залежністю 2-го степеня $R^{2}=0,9121$ (рис. 5). Передано на сторону іншим підприємствам 2955 тис. т, а решту було видалено на сміттєзвалищах та полігонах - 504 тис. т (рис. 6) (Dovkillia, 2017).

Відходи I класу небезпеки з 2000 по 2017 рр. змінюються за поліноміальною залежністю 2-го степеня $\left(R^{2}=\right.$ 0,7103) (рис. 7). На 2017 р. утворено 40 т відходів I класу небезпеки, 503 т відходів II класу небезпеки, 2102 т відходів III класу небезпеки. Обсяги відходів IV класу небезпе- ки 32010 по 2017 рр. становили: 2010 р. - 2483289 т, 2011 p. - 3460339 т, 2012 p. - 3348786 т, 2013 p. 2650457 т, 2014 p. - 3322559 т, 2015 p. - 2951855 т, 2016 p. - 2771664 т, 2017 p. - 2539460 т (рис. 8).

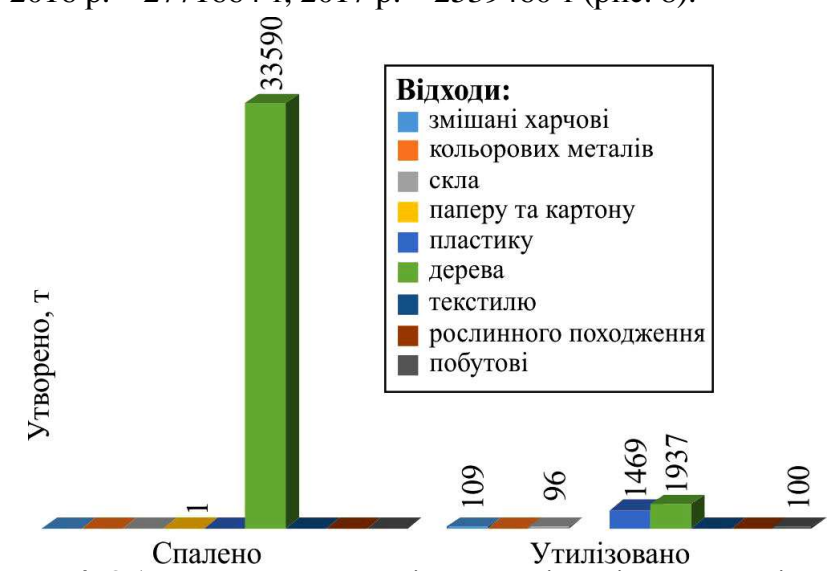

Рис. 4. Обсяг спалених та утилізованих відходів за категоріями матеріалів у 2017 р. у Львівській області

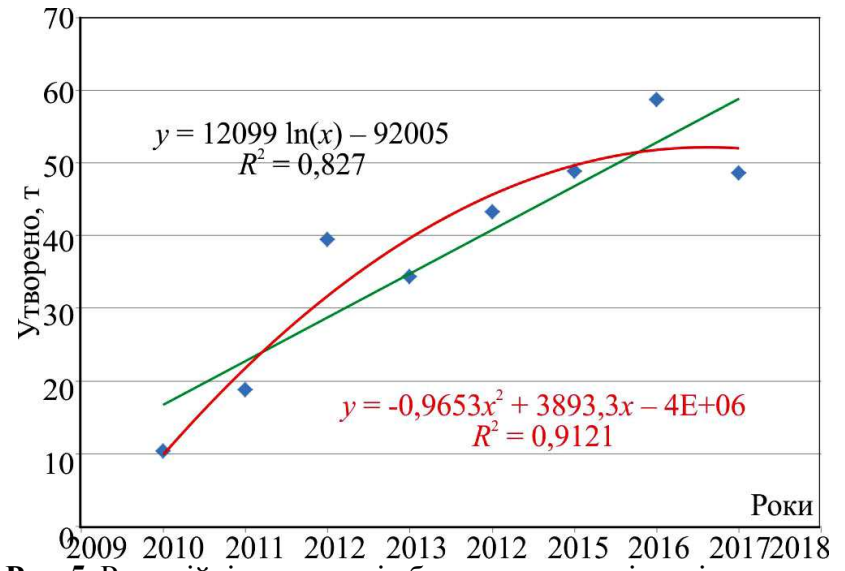

Рис. 5. Регресійні залежності обсягу спалених відходів у

Львівській області для отримання енергії

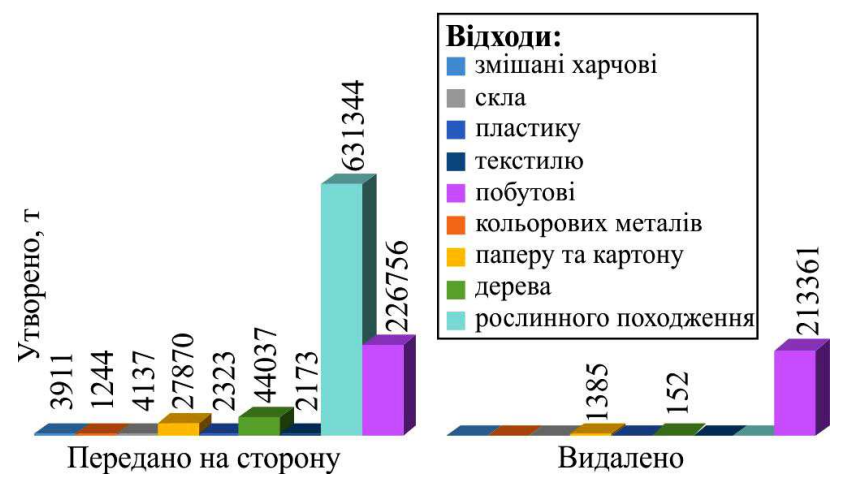

Рис. 6. Обсяг видалених та переданих на сторону відходів за категоріями матеріалів у 2017 р. у Львівській області

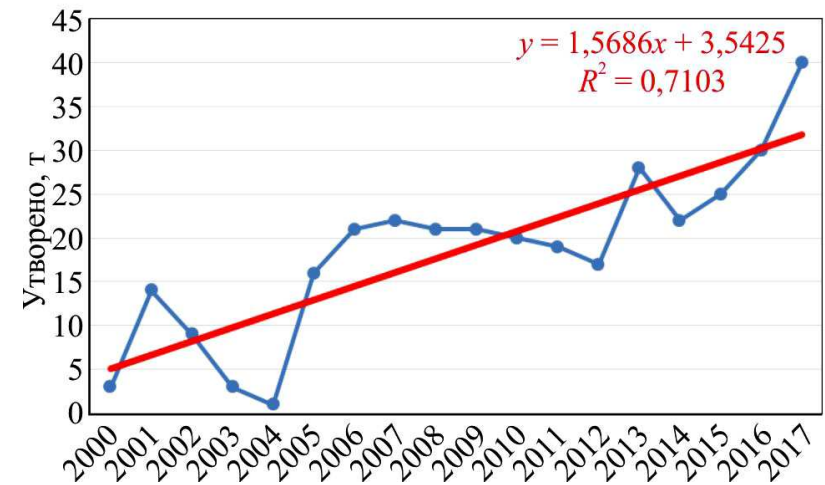

Рис. 7. Показники утворення відходів I класу небезпеки у Львівській області за 2000-2017 pp. 


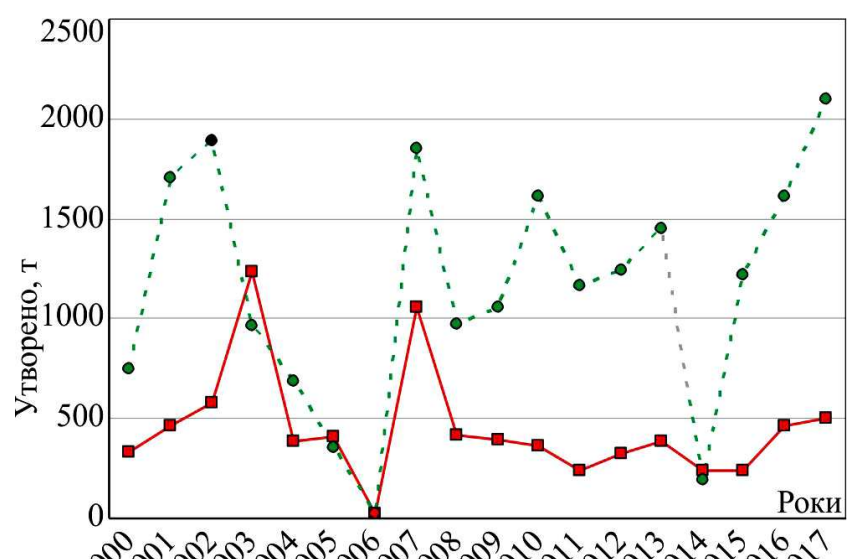

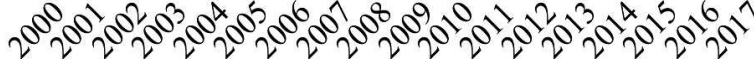

Рис. 8. Показники утворення відходів II і III класу небезпеки у Львівській області за 2000-2017 pp. (зеленим - III клас небезпеки, червоним - II клас небезпеки)

Для сталого розвитку України потрібно впроваджувати інтегровані системи управління відходами на регіональному та локальному рівнях. Для оптимальної моделі управління відходами необхідно передусім запобігати утворенню відходів та повторно використовувати їх і тільки тоді видаляти їх (рис. 9) (Koval \& Pohrebennyk, 2018).

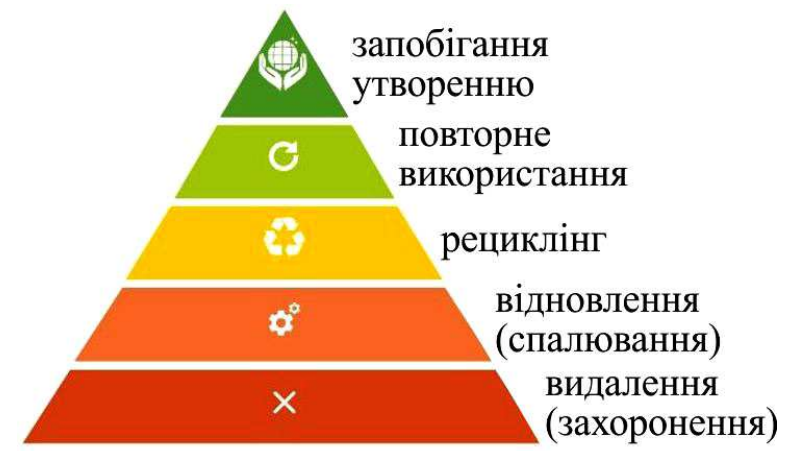

Теперішня ситуація в Україні

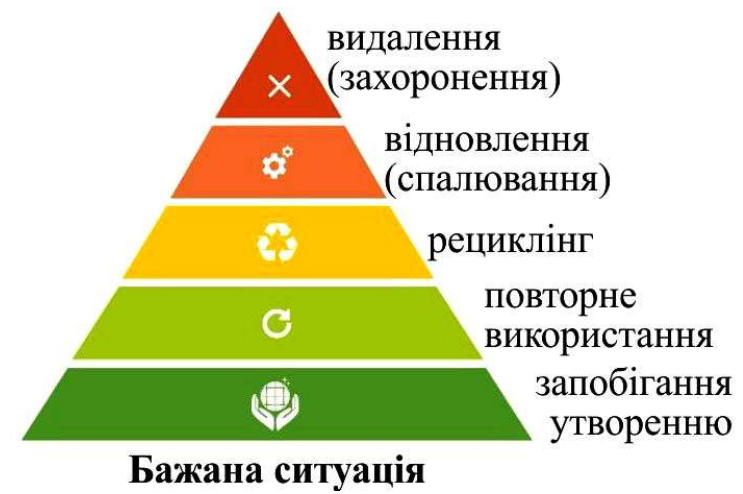

Рис. 9. Ієрархія управління відходами

Висновки. Проаналізовано сучасний стан управління відходами в Україні та у Львівській області. Встановлено, що нині в Україні немає ефективних методів та систем управління відходами.

Проаналізовано тенденції утворення та утилізації відходів у Львівській обл. за 2010-2017рр. Виконано регресійний аналіз зміни обсягу спалених відходів у Львівській обл. для отримання енергії і зміни показників утворення відходів I класу небезпеки. Аналіз цих досліджень дасть змогу спрогнозувати зміни обсягів відходів у Львівській області.

\section{Перелік використаних джерел}

Andronov, V. A., Ivanets, H. V., Kaluhin, V. D., \& Tiutiunyk, V. V. (2017). Naukovo-tekhnichni osnovy kompleksnoi systemy monitorynhu zon ekolohichnoho zabrudnennia, yaka vkliuchaie avtomatyzovani prystroi kontroliu ta bezpilotni litalni aparaty. Tekhnohenno-ekolohichna bezpeka, 2, 18-26. [In Ukrainian].

Babaiev, V. M., Panov, V. V., Khailo, Ya. M., \& Horokh, M. P. (2017). Kompleksna systema upravlinnia u sferi povodzhennia $\mathrm{Z}$ tverdymy pobutovymy vidkhodamy, Komunalne hospodarstvo mist, 130, 1-9. [In Ukrainian].

Bodnar, I. L., \& Poltorachenko, L. I. (2011). Systemy povodzhennia z tverdymy pobutovymy vidkhodamy v ukrainskykh mistakh, rol miskoho naselennia $v$ rozdilnomu zbyranni smittia ta rekomendatsii dlia orhaniv mistsevoho samovriaduvannia. Kyiv: PROON/MPVSR, 47 p. [In Ukrainian].

Bukhta, I. O. (2018). Problemy povodzhennia z tverdymy pobutovymy vidkhodamy u misti Lvovi. Naukovyi visnyk Khersonskoho derzhavnoho universytetu, 8, 13-20. [In Ukrainian].

Dovkillia. (2017). Statystychnyi zbirnyk "Dovkillia Lvivskoi oblasti" za 2017 rik, 144 p. [In Ukrainian].

Filipovych, V. Ye., Kudriashov, O. I., \& Mychak, A. H. (2015). Dystantsiinyi ekolohichnyi monitorynh zvalyshch tverdykh pobutovykh vidkhodiv. Ukrainskyi zhurnal dystantsiinoho zonduvannia Zemli, 4, 32-36. [In Ukrainian].

Kalyn, B. M., Matsuska, O. V., \& Romanyshyn, I. H. (2017). Analiz povodzhennia $\mathrm{z}$ pobutovymy vidkhodamy na mistsevomu rivni. (Ser. Silskohospodarski nauky). Naukovyi visnyk Lvivskoho natsionalnoho universytetu veterynarnoi medytsyny ta biotekhnolohii imeni S.Z. Gzhytskoho, 19(79), 145-149. [In Ukrainian].

Koval, I. I., \& Pohrebennyk, V. D. (2018). Orhanizatsiia intehrovanoi systemy upravlinnia TPV dlia Lvivskoi oblasti. Zakhyst navkolyshnoho seredovyshcha. Enerhooshchadnist. Zbalansovane pryrodokorystuvannia: Materialy V Mizhnarodnoyi konhres, Lviv, September 26-29, 2018. (45 p.). Lviv: Vydavnytstvo Lvivskoi politekhniky. [In Ukrainian].

Krupka, N. O., \& Lototska-Dudyk, U. B. (2015). Problema utvorennia, obrobky ta utylizatsii vidkhodiv u Lvivskii oblasti. Dovkillia ta zdorovia, 1, 62-67. [In Ukrainian].

Mitryasova, O., Staddon, Ch. (Eds), Pohrebennyk, V., \& Podolchak, I. (2016). Impact of lviv municipal solid waste landfill on water bodies. Water security. Mukolaiv: PMBSNU - Bristol: UWE, pp.170-181.

Pavlikha, N. V., Dubynchuk, L. I., \& Androshchuk, I. V. (2016). Systema intehrovanoho upravlinnia vidkhodamy yak skladnyk sotsialno-ekonomichnoho rozvytku mista. Visnyk ONU im. I.I. Mechnikova, 10(52), 84-87. [In Ukrainian].

Petruk, V. G., Stalder, F., Ishchenko, V. A., Vasylkivskyi, I. V., et al. (2016). Household waste management. The European experiences. Vinnytsia: "Nilan-Ltd.", 184 p.

Petruk, V. H. (Ed.). (2007). Intehrovane upravlinnia ta povodzhennia z tverdymy pobutovymy vidkhodamy $u$ Vinnytskii oblasti. Vinnytsia: Universum, 160 p. [In Ukrainian].

Samoilik, M. S., \& Molchanova, A. V. (2017). Ekolohichni aspekty vplyvu polihoniv tverdykh pobutovykh vidkhodiv na navkolyshnie seredovyshche. Filtrat. Visnyk Poltavskoi derzhavnoi ahrarnoi akademii, 1-2, 88-91. [In Ukrainian].

Scheinberg, A. (2008). Closing the Circle: Bringing Integrated Sustainable Waste Management Home. VNG International.

Shanina, T. P., Hubanova, O. R., Klymenko, M. O., Safranov, T. A., et al. (2012). Upravlinnia ta povodzhennia $z$ vidkhodamy. Odesa, 270 p. [In Ukrainian].

Vadivala, Keval, \& Vagnani, Minakshi. (2015). Integrated solid waste management based on 3Rs. International journal of advanced research in engineering, science and management (UJARESM), 1-6.

Worlds Cities. (2009). Solid Waste Management in the Worlds Cities. Forthcoming UN-HABITAT Report. 


\section{TRENDS OF DEVELOPMENT OF METHODS AND MANAGEMENT SYSTEMS OF WASTE}

Today, the sustainable development strategy is a priority for achieving harmony between economic performance growth, social stability, and environmental protection. Ensuring the sustainable development of any state is accompanied by the creation of a safe environment for present and future generations. Therefore, environmental safety is an integral part of sustainable development. Abroad, wastes are disposed of faster than they accumulate, alternative methods and environmental materials are used that minimize their formation. It used harmful materials that pollute the environment, as well as no ecological methods of waste disposal in Ukraine. One of the most important and most urgent problems of environmental pollution is the uncontrolled accumulation of waste and disposal at landfills in Ukraine. The purpose of the work is to analyze the main trends in the development of waste management methods and systems. Among theoretical methods, methods of analysis and synthesis were used to generalize literary sources and to identify the main areas of research. Formalization of the results of simulation was carried out using software-functional support MS Excel. The present state and problems of waste management in Ukraine and Lviv region are estimated. The tendency of constant growth of waste volume reveal. The dynamics of waste generation by categories of materials and hazard classes was deduced. The analysis of accumulation and utilization of waste in the Lviv region for 2010-2017 is carried out. The regression analysis of the volume of burned waste in the Lviv region has been carried out to obtain energy and change the indicators of waste generation and hazard class I. It was set up that the waste of class I of danger from 2000 to 2017 are changed in the polynomial dependence of the 2nd degree. Using these dependencies will allow you to predict changes in waste volumes in the Lviv region. For sustainable development of Ukraine, it is necessary to implement integrated waste management systems at the regional and local levels. For an optimal waste management model, it is necessary to prevent waste generation and reuse them first and to eliminate them only in the last instance.

Keywords: waste; waste management system; Lviv region; waste recycling; processing of statistical data; indicators of the waste accumulation and waste utilization. 